\title{
The effect of talent management practices on employee retention at the Namibia University of Science and Technology: Middle-level administration staff
}

\begin{tabular}{|c|c|}
\hline \multicolumn{2}{|c|}{$\begin{array}{l}\text { Authors: } \\
\text { Jacobina Amushila }{ }^{1} \text { (D) } \\
\text { Mark H.R. Bussin }{ }^{2} \text { (D) }\end{array}$} \\
\hline \multicolumn{2}{|c|}{$\begin{array}{l}\text { Affiliations: } \\
{ }^{1} \text { Department of Business } \\
\text { Administration, School of } \\
\text { Business and Economics, } \\
\text { Southern Business School, } \\
\text { Johannesburg, South Africa }\end{array}$} \\
\hline \multicolumn{2}{|c|}{$\begin{array}{l}{ }^{2} \text { Department of } \\
\text { Management, Faculty of } \\
\text { Management, Southern } \\
\text { Business School, } \\
\text { Johannesburg, South Africa }\end{array}$} \\
\hline \multicolumn{2}{|c|}{$\begin{array}{l}\text { Corresponding author: } \\
\text { Mark Bussin, } \\
\text { drbussin@mweb.co.za }\end{array}$} \\
\hline \multicolumn{2}{|c|}{$\begin{array}{l}\text { Dates: } \\
\text { Received: } 16 \text { Sept. } 2020 \\
\text { Accepted: } 30 \text { Mar. } 2021 \\
\text { Published: } 23 \text { July } 2021\end{array}$} \\
\hline \multicolumn{2}{|c|}{$\begin{array}{l}\text { How to cite this article: } \\
\text { Amushila, J., \& Bussin, M.H.R. } \\
\text { (2021). The effect of talent } \\
\text { management practices on } \\
\text { employee retention at the } \\
\text { Namibia University of Science } \\
\text { and Technology: Middle-level } \\
\text { administration staff. SA } \\
\text { Journal of Human Resource } \\
\text { Management/SA Tydskrif vir } \\
\text { Menslikehulpbronbestuur, } \\
\text { 19(0), a1485. https://doi. } \\
\text { org/10.4102/sajhrm. } \\
\text { v19i0.1485 }\end{array}$} \\
\hline \multicolumn{2}{|c|}{$\begin{array}{l}\text { Copyright: } \\
\text { (C) 2021. The Authors. } \\
\text { Licensee: AOSIS. This work } \\
\text { is licensed under the } \\
\text { Creative Commons } \\
\text { Attribution License. }\end{array}$} \\
\hline \multicolumn{2}{|l|}{ Read online: } \\
\hline 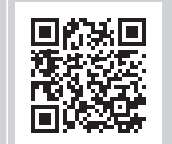 & $\begin{array}{l}\text { Scan this QR } \\
\text { code with your } \\
\text { smart phone or } \\
\text { mobile device } \\
\text { to read online. }\end{array}$ \\
\hline
\end{tabular}

Orientation: Talent management (TM) practices in the competitive corporate environment and the success and profitability in an institution can affect employee retention, the institution's objective achievements and the contribution to Namibia's economic growth.

Research purpose: The primary aim of the study was to determine if TM can influence the retention and turnover of employees at the Namibia University of Science and Technology (NUST), to explore the benefits that the institution can achieve by implementing TM and to study retention strategies that the institution can adopt to reduce turnover.

Motivation for the study: Limited research existed regarding the execution of best practice TM in this institution. New ways need to be engaged for employees to stay employed longer at the institution.

Research approach/design and method: The qualitative research design was implemented, with a target population of 39 administrative middle-level staff at NUST. Semi-structured interviews were conducted and research articles were reviewed. The data were analysed via qualitative content analysis that identified major themes.

Main findings: This study found a relationship between TM and employee retention and concluded that synchronisation of TM practices and employee retention initiatives led to reduced employee turnover. A model was recommended.

Practical/managerial implications: To implement and achieve TM properly, line managers and HRM managers should identify what hinders and facilitates TM.

Contribution/value-add: This study will contribute to research of TM in Namibia and to the field of HRM in the public sector, particularly in the tertiary education area.

Keywords: talent management; employee retention; namibia; employee turnover; human resources management; retention strategies; talent; talent strategies.

\section{Introduction}

\section{Orientation}

Talent management (TM) is one of the modern functions of human resource management (HRM) and the most inspiring topics in management (Hatum \& Preve, 2015). Talent plays an important role as a part of the HRM function in managing all employees within the organisation that leads to high performance (Tetik, 2016, p. 44). The role of HRM has rapidly changed from only concentrating on hiring, employee benefits and payroll to strategic human resources whereby the focus is on sustaining and driving business strategies. This raises questions about the necessity of re-skilling of HRM functions (Sparrow \& Makram, 2015, p. 249). This represents a major shift in how business executives view the value of HRM, as they understand the strategic value of TM and the impact that strong talent can have on financial outcomes (Silzer \& Dowell, 2010, p. 3). Silzer and Dowell (2010, p. 3) further state that 'talent is becoming recognised as a core competitive asset in any business organisation and serves as a currency of business'.

Namibia has been facing major challenges in retaining talent in most key sectors of the economy (Deloitte, 2015, p. 4). According to Letchmiah and Thomas (2017), it is still a major concern for 
many organisations to retain top-performing employees and thus, leadership strength is negatively affected. Talent management (TM) is the process that ensures an organisation has access to the human capital and helps in attracting, developing, engaging, retaining and utilising talent to the mutual benefit of the business and employees (Bussin, 2014, p. 17). However, employee retention can be defined as 'an organisation's ability to hold and keep in the possession and to engage the services of high potentials and value contributors in mission-critical and scarce skills positions' (Bussin, 2014, p. 26):

Organisations used to view talent as an audience, like fish waiting to be caught and not as a community, an ecosystem or fish swimming all over the global talent pool that are harder to catch. (Frost \& Turner, 2016)

\section{Research purpose and objectives}

Talent management, as such, is well researched in most parts of the world; however, it is limited in Namibian industries, as it is a fairly new approach in many organisations in Namibia. Therefore, although the shortage of talented workforce has attracted vast attention, the literature gives little recommendations on how to deal with it. The researcher is of the opinion that the problem is that organisations are still attached to the old perception of human resources and thus, there is a lack of understanding on the effects of TM on employee retention. Thus, the Namibia University of Science and Technology (NUST) may continue to face challenges in retaining key employees or absenteeism if TM is not implemented. The institution may extend its recruiting to foreign labour markets. Neither the NUST nor the Ministry of Education has commissioned to research and explore recruitment and retention trials facing NUST and the higher education sector in general to analyse the root causes (Van Hoof, 2020). The institutions of higher learning are vital to the success and growth of the Namibian economy. Retention of highly talented employees appears to be a concern at NUST given a high staff turnover (Deloitte, 2020). Research focused on retaining highly skilled employees might influence the institution's success and growth, especially employees who are the key drivers in steering the institution in the right direction. If the challenges of retention are not addressed, this will probably negatively affect the university's overall performance in terms of growth and professional support service to the education sector (Nambira \& Enkali, 2019, p. 4). There might be a repeat of the threat in 2012 of employees striking, because of a lack of salary and increment benefits (NUST annual report: 2013). When employees strike, major drawback to the institution are caused because the absence of administration staff hinders service delivery to the students.

The researcher was motivated to undertake this study regarding employee recruitment, turnover and retention of high talent because it is deemed necessary by the fact that high performing and talented employees continue leaving the institution sighting similar reasons for leaving. It is envisaged to propose recommendations that will assist NUST in addressing challenges faced by the institution. The researcher attempted to obtain an understanding and insight into the institution's recruitment and retention strategies.

To address the scarcity of literature that exists on the relationship between TM and employee retention within NUST and to understand whether implementation of TM can reduce employee retention, the following objectives will be explored:

1. To determine the impact of TM on employee retention at NUST.

2. To find the benefits that the institution can achieve by implementing TM.

3. To formulate the retention strategies adopted by the institution to reduce turnover.

4. To determine the effect that TM has on employee turnover.

5. To explore the relationship between TM and employee retention at NUST.

\section{Literature review}

\section{The conceptual clarification of talent}

According to Silzer and Dowell (2010):

[T]he term talent dates back to ancient Greeks and biblical times, starting as a measure of weight, then becoming a unit of money and later meaning a person's value or innate abilities. (p. 13)

We might now refer to a person with innate abilities as a 'gifted' individual. There is no universal accepted definition of what talent constitutes, as different organisations and different sectors define talent in a wide range of ways. A few will regard employees who are the current top performers as talent, whilst others also classify those with 'high potential' (HIPO) as talent (Bussin, 2014, p. 46). Bussin (2014) further adopted a definition as stated in the Chartered Institute of Personnel and Development (CIPD) (2012) that:

[T]alent consists of those individuals who can make a difference to organisational performance either through their immediate contribution or in the longer term, by demonstrating the highest levels of potential.

Letchmiah and Thomas (2017, p. 3) define a 'talented employee as the one who drives consistent excellent business performance through competency, commitment and involvement and has shown the potential to move up'. Silzer and Dowell (2010, p. 13) further stated that in an organisation, talent could refer to:

- an individual's skills and abilities (talents) and what the person can do or contribute to the organisation

- a specific person usually implying she has specific skills and abilities in some area, or

- a group of employees in the organisation impacting superior performance and potential. 
Egerova (2014), as cited by Van Zyl, Mathafena and Ras (2017, p. 2), believes that:

[T] he increasing attention to talent is affected by factors such as globalisation, knowledge-based reimbursement, changing the world of labour and also new forms of organisational and demographic changes. In some organisations, talent does not make a great difference about organisational performance. (p. 2)

'Many bureaucratic organisations have been designed and structured so individuals do not need to perform at a superior level, they simply need to perform at an adequate level' (Lawler, 2017, p. 10).

\section{Talent management defined and the need for attention}

According to Blass (2009, p. 17), cynics argued that 'TM is just another human resources fad, but few fads seem to have turned themselves into a new trench in the labour market'. The roots of TM can be traced back to the downsizing and outsourcing trends in the 1990s, including the slimming down of graduate recruitment schemes. TM became more popular after McKinsey \& Company coined the term 'War for talent' in 1997 for their research on TM and practices (Van Zyl et al., 2017, p. 1). Bussin (2014) stated that:

$[M]$ any organisations responded to this 'wake-up call' by building methodologies, processes, and talent review mechanisms aiming to attract and retain critical talent and skills required to compete and 'win the war'. (p. 85)

According to Van Zyl et al. (2017, p. 2), TM has progressed quickly up the corporate agenda in the recent years, which is apparent from the number of research papers published over the last few years. Typically, according to Poisat, Mey and Sharp (2018, p. 2), TM has three mainstream definitions: firstly, it is the description of a new HRM term; secondly, an insinuation of succession planning; and finally, the general management of talented individuals in the organisation. Bussin (2014) further stated that:

$[E]$ ven after many years, organisations are still struggling with ensuring they have the right people, with the right skills, doing the right things, at the right time to achieve business results.

Armstrong (2012, p. 719) defines TM as 'ensuring that the organisation has talented people it needs to attain its aims and objectives'. The term TM may simply refer to management succession planning or management development activities. Mahlahla (2018) mentioned that TM has three main goals, namely:

- to identify, handpick and develop employees who provide superior performance and stimulate others to perform with the same confidence,

- to find, develop and position highly qualified backup personnel for key positions in the organisation,

- to allocate resources, namely, rewards, training, coaching, job assignments and other inducements to employees based on their genuine or potential contribution to excellence.
Chee's (2017) study on TM mentioned effective TM planning, leadership, continuous support, organisational unity, work-life balance and other environmental factors where important strengths to retain talented employees in the organisation.

According to Riccio (2010, p. 17), there is a shortage of TM in educational institutions as they spend too little time identifying their future leaders whilst claiming to be institutions for higher learning and training. Several researchers share the same view that there is a need for TM in every organisation and it must be incorporated to create and maintain a strong association of human resources development. Letchmiah and Thomas (2017) mentioned that TM relates to the implementation of integrated strategies that are designed to increase efficiency by developing improved processes for attracting, developing, retaining and utilising individuals with required talents and aptitude to meet existing and future organisational needs. Overall, according to Van Zyl et al. (2017, p. 2), there seems to be a lack of linkage between TM practices and the broader human resources system.

\section{Employee retention}

Talent retention is all the activities and practices used by organisations to avoid the departure of talent. 'Because of the high costs associated with losing talent, it is difficult for organisations to gain and maintain a competitive advantage without retaining their talent' (Ott, Tolentino, \& Michailova, 2018, p. 16). Kibui, Gachunga and Namusonge (2014, p. 421) mentioned that employee engagement and employer-employee relationship should be durable, constant and link the employee to the organisation's common values and by how the organisation responds to the needs of the employee. However, the South African Board for People Practices found in its annual HRM survey as cited by Erasmus, Grobler and Van Niekerk (2015, p. 34) that a significant 32\% of South African organisations do not concern themselves with retention phenomenon, but at least $46 \%$ indicated the problem as a concern.

According to Lawler (2017), a major issue in talent development is talent retention. Talent retention as identified by Sparrow and Makram (2015, p. 250) is talent protection and is the process whereby organisations develop isolating implements to protect its talent resources from being lost to other organisations. Turnover is expensive from an administrative and development viewpoint, but its greatest expense often is the opportunity of the talent lost. Arguably, the economic downturn at the start of this decade has caused many employees to stay in jobs that they might have left earlier. As the economy recovers, up to half of the managers could be looking for new jobs as long hours, lower salaries and benefits coupled with their perception of ungrateful and greedy senior leadership, which propels disgruntled employees to leave as more opportunities become available (Blass, 2009, p. 13). The study of Onyango, 
Nzulwa and Kwena (2017, p. 637) revealed that employee retention involves taking measures to encourage employees to remain in the organisation for the maximum period of time. Onyango et al. (2017, p. 638) further define employee retention as a systematic effort by employers to create and foster an environment that encourages employees to remain with the organisation.

A significant number of employees leave their jobs before they have spent a year with the organisation (Lawler, 2017). Retention strategies should be adopted to strengthen the ability of organisations to attract and retain their workforce. Employee retention is important for building a productive, committed and healthy workforce (Onyango et al., 2017, p. 637). Kibui et al. (2014, p. 422) emphasised that retention is mainly to prevent the loss of competent employees in the organisation, which could cause harm to productivity and service delivery. Remarkably, in understanding challenges faced by organisations to retain staff, it is vital to understand employee turnover (Dhanpat, Modau, Lugisani, Mabojane, \& Phiri, 2018).

\section{The talent management strategies to enhance retention in an organisation}

A TM strategy according to Armstrong (2012) consists of a view on how the TM processes blend with the organisation's overall objective to acquire and nurture talent wherever it is. According to Poisat et al. (2018), TM strategies must be adjusted to accommodate the diverse values, features and attitudes towards work and corporate world view of the different generational associates working together. According to Bussin (2014, p. 81), succession management is one tactic to overcome leadership succession risks. Koranteng (2014, p. 23) further suggested that a succession system would be more successful if it is highly formalised, has a system of checks and balances, has adequate resources, has broad information, uses capability rather than governmental criteria for individual selection and has reliable staff. According to Robertson (2015), coaching new employees is important to incorporate coaching into a TM strategy to enable an increase in employee engagement and achieve talent development goals such as problem-solving capabilities and strategic thinking. TM suggests that organisations must be purposeful with their retention techniques to help engaging with newly recruited employees considered top performers. 'The techniques may include selection techniques, developmental opportunities, and mobility within the organisations and promotion prospects' (Letchmiah \& Thomas, 2017). According to Davis (2016, p. 25), creative assignments is stating that "one cherished resource many organisations overlook is the value of existing employees. Attention on recruiting top talent is a priority for an organisation but so is the talent. Creative assignments is one of the many ways that organisations employ to increase the efforts and abilities of employees whilst performing tasks.

According to Bussin (2014, p. 74), talent development is learning and development of talent and is one of the most important components of a TM strategy and the development needs to be customised and experiential. Developing the right talent and doing so in the correct way is critical to the effectiveness of each organisation (Lawler, 2017). The aim is to use the business strategy to explore the talent attraction and development that may occur. Leadership development according to Armstrong (2012) is rather an unfavourable statement for those who are leaders by birth although there is a saying that leaders are born not made. However, further defines leadership development as a sense to acquire, develop and utilise leadership capabilities or the potential for it. Armstrong (2012) suggested possible conditions for effective leadership development as clear learning objectives, the opportunity for active practice, relevant timely feedback, suitable follow-up activities and a suitable mix of training methods. Employee engagement is one fascinating concept that comes along every few years in the HRM field that is fuelled by an intense business need and introduced into practice so quickly that it creates consternation and confusion in research and academic communities (Silzer \& Dowell, 2010, p. 439).

\section{Constructive retention strategies}

All organisations are challenged with attracting and retaining a quality workforce to attain operational excellence and competitive advantage (Sparrow \& Cooper, 2017, p. 78). Dhanpat et al. (2018) mentioned that it is vital to note that when organisations recruit HIPO individuals, they must develop and implement retention strategies immediately to prevent employees from leaving. According to Turner and Kalman (2014), retention is not only about money but also a universal process that will span most aspects of an individual's management.

Mentorship programmes: Mentoring plays a key role in helping employees gain awareness into how senior leaders operate (Davies \& Kourdi, 2010, p. 66). Organisations having employees mentored is one of the valued and effective professional development prospects they can offer employees. New employees can learn the ropes from an expert through a wealth of guidance, encouragement and support that will provide personal and professional benefits that lead to better performance.

Recognition and rewards system: According to Letchmiah and Thomas (2017), employees who perceive contributions equal to the benefits they receive are less likely to leave their jobs. The appreciation can be as simple as leaving a small note on the employee table, sincere email, a gift card, an extra day off or, as a surprise to a deserving individual, an internal promotion. To succeed in the war for talent, organisations need to clearly understand how numerous reward factors influence whether talented performers stay or leave their jobs (Pregnolato, Bussin, \& Schechter, 2017).

Employee compensation: Mahlahla (2018) stated that other researches are on the opinion that the significance of financial compensation strategy on retaining employees varies as per individual and is not necessarily a motivator for everyone. 
Compensation plays a key role in attracting employees, improves an individual's organisational commitment and ensures employee retention (Dhanpat et al., 2018).

An ideal package may include a salary, 13th checks, medical aid, pension, and retirement plans, generous paid leave and paid studies.

Communication and feedback: Dhanpat et al. (2018) emphasise that proper and frequent feedback is vital in retaining employees because employees perceive organisational support and increase commitment in the longterm. It is crucial to regularly connect with each employee and not allow issues to build up.

Perform exit interviews: According to Amsbary and Powell (2018):

[S]ome people switch jobs, moving because of a better salary and benefits and working environments while others burn out by working too long and too hard at a single position.

It is very difficult for an organisation to figure out why an employee is leaving unless the employee is asked. That is why Amsbary and Powell (2018) revealed that:

$[I] \mathrm{t}$ is vital for an organisation to schedule an exit interview with all employees who decide to resign. Since an exit interview is the last meeting between an employer and an employee, it will give a last chance for the employee to contribute to the organisation's success. Organisations will be able to form trends and implement an effective change program to reduce or even avoid high turnover and improve retention.

\section{Benefits of talent management}

According to Sparrow and Cooper (2017, p. 51), TM has become a burning topic in management over the past few decades. The understanding of the TM topic has progressed in recent times, and the quality of experiential evidence has advanced and has countless benefits that organisations can utilise.

Retaining top talents: According to Letchmiah and Thomas (2017):

$[T]$ op-performing employees are at times unnoticed and seen as organisational assets. As a result, employees become unhappy with and detached from their current employers and begin to look for new job opportunities where they feel more valued and appreciated. (p. 2)

Erasmus et al. (2015, p. 34) highlight that retaining highquality talent is important to organisations as it eliminates the hiring, selection and onboarding costs otherwise suffered in replacing best professional talent.

Getting the right person for right position: Organisations that attract and retain the right talent and treat it well, reward it, develop it and deploy it correctly perform better than those that simply fill jobs (Lawler, 2017). The right person in the right job will give a better alignment between employee's interests and job profile that leads to increased job satisfaction and their needs.

Enhanced professional development decisions: Poisat et al. (2018) state that the work environment is important for employee satisfaction and a positive relationship between management and employees. They further indicate that such a relationship needs to be of mutual respect, trust and confidence in employee's capabilities.

Improved hiring: The success of an organisation's hiring strategy is determined by an effective TM system that leads to a quality workforce (Van Zyl et al., 2017). As the saying goes, there is no successful talent at the top without bottom talent.

Competitive advantage: Engaged, motivated and skilled employees work in the strategic direction of the organisation's goals and objectives, which creates a competitive advantage (Ott et al., 2018, p. 17).

Employee motivation and commitment: Poisat et al. (2018) state that that an organisation's effective TM strategy helps them to keep their employees motivated and committed. A motivated workforce discourages employees to leave the organisation and do their job effectively. Not all employees are driven by money, so they will need to feel engaged and feel safe to be fulfilled.

\section{Employee turnover}

Employee turnover is a concern in many worldwide organisations, which decreases the operating costs of organisations, leaving significant effects on talent loss and disruptions in business activities (Dhanpat et al., 2018). Theron, Barkhuizen and Du Plessis (2014) distinguish between avoidable turnover (identified as those employees who express turnover intentions but do not resign) and unavoidable turnover (described as voluntary resignations because of various reasons that organisations have no control over). Narayanan (2016, p. 35) states that over the past few decades, management practitioners have shown more interest in the labour turnover model as it is always a significant concern to many organisations.

Mamun and Hasan (2017, p. 63) blame it on the organisation's top management as they pay less attention and do not concentrate on this major issue, as they are possibly not capable of recognising the situation on how labour turnover harms the organisation's overall performance. Ahmed, Sabir and Khoza (2016, p. 89) narrate that employee turnover results in the access and opportunity to enter into new employment. Armstrong (2012) believes that it is necessary to measure labour turnover and calculate its cost to estimate future losses for planning and also to recognise the motives on why people leave their employment. Numerous researchers, including the studies of Ahmed et al. (2016, p. 90), highlight similar factors on why people leave their jobs, such as lack of proper induction and orientation, a 
mismatch between experience, qualification and salary offered, poor training and development, low-grade working environment, career promotion and bad influence of co-workers. Besides these causes, Silzer and Dowell (2010, p. 240) added that employees also leave because they do not feel appreciated and because management fails to set clear job expectations for prospective employees.

\section{Challenges associated with talent management}

According to Sparrow, Scullion and Tarique (2014) 'there are many debates and criticisms about the way TM is applied in practice and the topic is still lacking a definition and needs theological growth'. TM offers a fresh approach to addressing the hot topic through human resources affluence as many challenges need to be considered, especially the organisational level and employee level challenges (Silzer \& Dowell, 2010, p. 753).

The study of Mogwere (2014, p. 23) stipulates that it is important to remember that challenges differ from organisation to organisation even from one continent to another regarding experiencing and a shortage of talent'. Mogwere (2014, p. 23) uses Africa as an example, where organisations lack the ability to hire and retain a qualified workforce and face challenges such as poor salaries, working conditions, proper employee engagement and reduced rewards. Another challenge according to Mogwere (2014, p. 23) emphasises talent shortage resulting from the deteriorating quality of the education system, because of low funding caused by inadequate education and lack of facilities, equipment and tools; the most critical challenge is the lack of qualified academic staff. The studies of Koranteng (2014, p. 30) added that factors such as the current economic crises, hiring and selection, cultural diversities and proper human resources planning are affecting the management of talents.

\section{Research design}

This study was performed based on a qualitative research design to understand the effect of TM on employee retention at NUST. According to Bertram and Christiansen (2014, p. 40), 'research design is a plan of how the researcher intends to methodically collect and analyse the data that is needed to answer the research questions'. The research information was solicited from both primary and secondary data. The researcher made use of a one-on-one interview with semistructured questions with the study participants.

\section{Research approach}

The researcher adopted a qualitative research method by making use of a case study approach because of the complexity and nature of the study. According to Beaudry and Miller (2016):

[A] qualitative research remains constant among other approaches with distinctive features such as, the research focuses on people in their natural settings, samples are small and they are sensitive to setting and purpose, data analysis is inductive, and the researcher was the key instrument for data collection and is engaged with visible players. (p. 39)

\section{Research strategy}

The primary source of data for this study was obtained through the semi-structured interviews administered to the participants for both the middle-level administrative employees and the director of HRM.

\section{Research method}

\section{Research setting}

Interviews were conducted at NUST, which is a Namibian public tertiary educational institution that has recently transformed to a full-fledged university. The institution has grown since its academy years and employed close to 1000 employees, which comprise academic and administrative staff, and enrolled about 13000 students in 2019. The research was conducted according to ethical rules, procedures and guidelines of NUST obtained from the department of the deputy vice-chancellor of innovation and research.

\section{Entrée and establishing researcher roles}

The primary researcher performed the role of interviewer.

\section{Research participants and sampling methods}

The 39 potential participants of the study were identified by finding all the names of the individuals that fitted the criteria for the target population. Detailed informed consent forms were e-mailed to participants seeking permission and approval to conduct interviews for gathering responses determining the influence of TM on employee retention of the sample population to address the research questions. An introductory e-mail on the setting up of convenient interview meeting times and venues that ensured confidentiality was sent out to individuals who had by that time consented to participate in the study. Interviews were conducted by first explaining the interview protocol and setting out the aims and objectives of the study. At the end of data collection through the structured interviews, 22 participants were interviewed, which represented a response rate of almost 58\%. It was considered sufficient because data saturated well before then.

According to Bertram and Christiansen (2014, p. 59), 'sampling encompasses making decisions about which people, settings, behaviours, and events will be included in the study by deciding how many individual groups or objects will be observed'. The unit of analysis of this research paper was the administrative middle-level management staff of NUST, because this group of administrative staff is where key activities of NUST revolve.

The researcher approached 39 participants who met the criteria from all 13 administration departments of NUST, meaning it was 3 participants from each department. Of the 
possible 39 participants approached, 22 were available and able to make the interviews. Data saturated long before all 22 interviews were completed. The sample selected was of the participants in employment for not less than 1 year because they have the knowledge based on the research problem. The participants selected were interviewed and the semi-structured were from the office of the vicechancellor; office of the deputy vice-chancellor, administration and finance; office of the bursar; office of the registrar; human resources; library; centre for open and lifelong learning; department of auxiliary services; centre for teaching and learning; centre for corporative education unit; dean of students; centre for enterprise development and the department of information and communication technology.

\section{Data collection methods}

The data collection method was through semi-structured interviews with the participants selected as the middle-level administration staff members. The respondents answered the interview questions freely according to their ethics and principles without being exposed. The researcher adopted the use of open-ended and closed-ended questions to make it easier for data analysis. Semi-structured interviews lasted from 30 to 45 minutes and the researcher made audio recordings of all the interviews that were later transcribed and analysed.

\section{Data recording}

The researcher maintained a file to keep all the handwritten notes of what was said by the respondents because it was easy to lose crucial information if the papers were loose and no respondent would want to be interviewed twice and time was of essence. With the fast-paced technology world, the researcher made use of audio recording that was transcribed before analysis began.

\section{Strategies employed to ensure data quality and integrity}

The most cited concept of trustworthiness of quality criteria of this research method is that of Guba and Lincoln of 1985 and thus, this research's trustworthiness was established by using credibility, transferability, dependability and conformability strategies. To that extent, the researcher ensured that data and data analysis will be credible and trustworthy. The participants were encouraged to support their statements with examples where necessary and the researcher studied the raw data to develop a theory to provide intended insight. Characteristics of data were examined by developing codes and core categories, recording and labelling them. The researcher ensured sending all interview transcripts back to respondents for feedback and correct any misinterpretations through member checking. The researcher made use of good descriptions of the respondent's answers and the full research process. This enabled the reader to see if findings were in harmony with their experiences and to make transferability judgement decision. To increase dependability, the researcher ensured that the research process is logical, traceable and clearly documented.

The proposed research was conducted according to ethical rules, procedures and guidelines of NUST obtained from the department of the deputy vice-chancellor of innovation and research. Permission to conduct the research was obtained from the registrar, the consent form was developed to safeguard the participants and consent was sought from all participants before starting the interviews. According to Wiley (2013, p. 42), in the research setting, discretion means that identifiable information about individuals, collected during the process of research, will not be disclosed and that the identity of research participants will be protected through a process designed to ensure anonymity, unless they specified to be identified.

\section{Data analysis}

According to Beaudry and Miller (2016, p. 45), 'in qualitative research, data analysis depends on the procedures for organising and reducing data and summarising results'. After collecting the information, the researcher carefully read the handwritten notes and listened to the audios to identify patterns amongst the data collected. Responses differed from the respondent's different ways of answering the question on how they felt and thought. Thereafter, responses were transcribed into an excel worksheet for data analysis. It is a crucial step for analysing and organising qualitative data to be able to understand, see and allocate codes to sensitive and indirect data collected throughout the study. Responses for each question were assessed and analysed for key words and phrases for which codes were allocated. The codes that were identified were then organised into one dataset applicable to each question. The dataset was then analysed for resemblances, differences and replicate themes and organised order theme bands, categorised patterns and emerging themes for which each theme was named. This report underscored the themes for TM and employee retention, which emerged from the responses utilising thematic analysis technique. Thematic analysis is a search for patterns and themes within a dataset that discovers commonalities of capabilities, thoughts, beliefs, opinions and views, thus addressing the research questions being examined.

\section{Reporting style}

The study was reported as per the guidelines of the American Psychological Association (APA).

\section{Ethical considerations}

Ethical clearance was obtained from the Southern Business School, SBS-20201-0014-MM.

\section{Results}

The results are presented against the objectives of the study. 


\section{Research objective 1: To determine the impact of TM on employee retention at the NUST}

The encounters of the study showed that NUST is not yet at the phase where it is supposed to be in terms of TM development and employee retention. At this stage, TM has not yet made significant progress and development to where it can influence employee retention. The findings exposed shortcomings in the implementation, such as the lack of overall leadership commitment that was found to be deficient and may impede delivery. The findings showed that the institution has invested in allocating fair salaries although it has not reached a point where non-monetary incentives have satisfied the policy of talent attraction and fulfil employee job satisfaction. Poor employee retention in NUST was also attributed to slow planning of developing a TM programme that could have been implemented ages ago, while others may be from the financial challenges that the institution was facing as a result of slow funding from the government.

\section{Research objective 2: To find the benefits that the institution can achieve by implementing TM}

The concept of TM has different meanings for different people, which means that the benefits of implementing a TM programme will differ from organisation to organisation. This is similar to the previous studies as most kinds of literature cited that TM implementation is crucial to recruit and develop talent not just for meeting today's needs but also keeping in mind the organisation's future. Thus, developing TM and managing it properly by keeping employees engaged and motivated is beneficial to NUST's sustainability. To achieve that, the findings expressed that developing a TM strategy in line with the institution's vision needs to be implemented.

There was a perception that TM improves employee commitment and support to employees throughout their employment and therefore retains top talents. The NUST has made it a priority to complete the implementation of TM to achieve competitive advantage in terms of retaining high performers in administrative operations.

\section{Research objective 3: To formulate the retention strategies adopted by the institution to reduce turnover}

This objective was to frame retention strategies that NUST is utilising to minimise employee turnover. This was made by establishing whether there was an understanding of the concept of employee retention and what it seeks to achieve in terms of what level the concept contributes effectively to the TM system. The findings revealed an insignificant percentage of lack of understanding of retention; many understood that retention strategies are necessary and critical for the institution to improve its capacity to retain its high performing employees. The respondents were not keen to identify institutional retention strategies, with individuals emphasising job dissatisfaction because of the institution holding on to traditional HRM practices. However, few respondents commended the strategy of allowing individuals to study with fees waiver options although it was limited compared to the opportunity given to the academics. The majority were rather suggesting strategies that would aid in reducing employee turnover and recommend for exit interviews to be performed to know the reasons behind employees leaving.

\section{Research objective 4: To determine how effective TM is on employee turnover in the NUST}

This research objective was to determine the effectiveness of TM process in NUST. The findings concur with the conclusions of various authors and kinds of literature mutually acknowledging that TM as a process ensures that the right skills are acquired, nurtured and retained by the organisations. The findings identified one primary reason that employees leave NUST is the lack of matching nonmonetary incentives with that of their competitors. However, career development, job satisfaction and performance management in TM are important factors influencing an individual's decision to stay. The results show that TM would anticipate HRM activities such as recruitment and selection, coaching, training and development and performance management to minimise employee turnover.

\section{Research objective 5: To explore the relationship between TM and employee retention at the NUST}

Many scholars, just like the findings of this study, revealed a positive relationship between the institution's TM systems and its employees. The findings further showed that employee retention is a major factor in reducing talented employees' turnover. Therefore, management should give much attention to talented staff to retain their services in the long-term.

It was perceived that talented employees always have high expectations regarding compensation packages but must be include attractive non-monetary benefits in the packages. Career development, job satisfaction and performance management appear to have a close association with low turnover rates maximising the institution's overall performance. The study concluded that TM cannot be separated from employee retention because they go hand in hand.

\section{Discussion}

\section{Outline of the results}

The main objective of the research study was to discover the influence of TM on employee retention at NUST. From the qualitative analysis of the results of the interview protocol, the study discovered that TM practices have a significant effect on employee retention at NUST. NUST has gradually benefitted from introducing TM and developing a performance management tool from the analysis yielding 
several positive outcomes, with the aim to largely benefit after the complete implementation.

The findings also observed the importance of top management playing their key role in the TM programme to ensure the practice of talent retention whilst minimising employee turnover. The results on talent retention strategies showed absent retention strategies except for the old traditional processes in place that helped little in retaining employees. The literature review revealed several retention strategies to challenge the attraction and retention of a talented workforce.

The study findings expect employees to gain more attractive $\mathrm{TM}$ benefits that can motivate them to be more loyal to the institution. The study findings state that employees must adjust to change for TM to help them achieve their personal goals and objectives to develop their personal growth. To validate the above findings and finding the way forward, the next step is to address the analysis from the results of the four themes that emerged. The findings from the first theme of talent attraction were to identify and understand the processes of attracting new hires. It was discovered that employees were more attracted to non-monetary incentives compared to monetary incentives. The findings showed the lack of career development is one of the major reasons that employees leave their jobs. In the findings, respondents stated the lack of growth opportunities within administration although the details were not given professionally of exit interviews. Findings noted was increased turnover in the past few years because of burnout and non-monetary incentives offered by other institutions that NUST could not match and now calls for solutions to remain competitive and retain key talent.

The major theme of employee turnover attracted job satisfaction as the sub-theme and findings revealed that employees suffered from job dissatisfaction. The findings suggest that managers do not pay sufficient attention to the performance of employees and ignore the importance of job satisfaction. The study discovered that performance will be emphasised by developing a performance management tool at NUST. The findings concluded that the institution should manage its performance management to strengthen its capabilities and competitiveness in the operating environment. The results of performance management provide a basis for self-development and in $\mathrm{TM}$ to ensure the support and guidance that people need to develop and improve.

\section{Practical implications}

The findings of this study have important implications for the employers, especially those in the education industry, and the advancement of knowledge in managing and retaining HIPO employees at the institution. The findings of this study help the line and HRM managers in developing and implementing successful TM practices that would help align the core objectives of the institution. The institution should develop retention strategies based on the needs of its top talents and control the strengths that the institutional culture encourages and provides. This allows the institution to have a competitive advantage against other competitors by developing a TM strategy that would be consistent and efficient simultaneously. This study will also provide a vision to the institution as to how TM influences employee retention, so the institution can improve in developing, promoting and retaining talent to meet the existing and future needs.

As compensation of non-monetary incentives, career development, job satisfaction and performance management had the most significance, the institution should pay much attention to these four factors to keep the employee with the institution for a longer time. Line management must assume responsibility and accountability for the outcomes of managing talent in their respective units and departments. Constant communication and feedback are to be carried out continuously by direct management with the employees in a professional, open and honest manner. Finally, the study would also enable us to promote transparency amongst the management and employees in increasing their performance and indirectly help the institution to increase their productivity and ultimately lead to institution profit. The recommended practices for this study will offer the direction to higher educational institutions in determining which of the TM strategies are more effective to retain employees and what urges them to stay and work with the institution on a long-term basis.

\section{Limitations and recommendations}

Many interviews were performed via Phone, Zoom or Teams. This limitation was because of the international outbreak of COVID-19 that led to the country's partial lockdown. The interventions were very strict because of the nature of spreading of the virus and thus led to social distancing and restricted travelling. Many respondents were not willing to risk attracting the virus. The challenge was also that respondents were not willing to provide the completely frank information as regard to the sensitivity of the study subject as they feared victimisation from top management. Another limitation was the lack of reliable responses as some of the data were recorded with cell phones, especially the ones gathered via the Phone app, and thus limited the research and analysis on some questions pertaining to this study.

Regarding empirical knowledge expansion, the study recommends to organisations and/or institutions wishing to restrict the drain of talent, increase job satisfaction to have well-motivated and effective employees and create better business results need to take practical steps to address these challenges. The strategies should increase the value of the organisation and preserve its sustainable competitive advantage. 
Regarding organisational recommendations, the following should be practiced by NUST:

- Policymakers should revise and improve the HRM policies, including their TM and retention policy, as HRM policies directly influence employees' working conditions.

- Implementation and correct application of talent retention strategies by applying the hierarchy of needs theory to understand employees' needs in the institution by predicting the actions and behaviours of employees under different situations.

- Creating proper rewarding structure to enhance job satisfaction and therefore retention that may include fair benefits from the employee rebate systems for all employees and at all levels.

- Introducing a 360-degree performance appraisal method built in the new developed performance management tool and trying to tap from internal talent pool before a vacancy is advertised to the public.

- Creating an insignificant incentive approach.

\section{Conclusion}

The Namibia University of Science and Technology has embraced the development of TM combined with the performance management tool as part of its HRM management operations and practices. From the findings and discussion, majority TM practices that were found to have been adopted by the institution have a relationship with employee retention. Talent management practices to a greater extent determine employee retention; NUST needs to develop other practices such as knowledge management, health and safety and also employee engagement. This research study also established that successful TM is driven by a talent mind-set in which managers in the institution regard TM as their responsibility and not the sole responsibility of the HRM department. Failing to retain high-performing employees in NUST is costly just as for any other organisation because of costs associated with high turnover. Talent management practices can facilitate the development of employees, enhance service delivery and also give NUST an enhanced group image.

\section{Acknowledgements Competing interests}

The authors have declared that no competing interest exists.

\section{Authors' contributions}

All the authors contributed equally to this work.

\section{Funding information}

This research received no specific grant from any funding agency in the public, commercial or not-for-profit sectors.

\section{Data availability}

Data sharing is not applicable to this article as no new data were created or analysed in this study.

\section{Disclaimer}

The views and opinions expressed in this article are of the authors and do not necessarily reflect the official policy or position of any affiliated agency of the authors.

\section{References}

Ahmed, Z., Sabir, S., \& Khoza, M. (2016). Impact of employee turnover on organisational effectiveness in telecommunication sector of Pakistan. IOSR Journal of Business and Management, 18(11), 88-96.

Amsbary, J.H., \& Powell, L. (2018). Interviewing in a changing world: Situations and contexts. New York, NY: Taylor and Francis. Retrieved from https://library.books24x7. com/assetviewer.aspx?bookid=137745\& chunkid=329184769\&rowid=4

Armstrong, M. (2012). Armstrong's handbook of human resource management practice. Kogan Page. Retrieved from https://library.books24x7.com/assetviewer. aspx?bookid $=47011 \&$ chunkid $=544534210 \&$ rowid $=3128$

Beaudry, J.S., \& Miller, L. (2016). Research Literacy: A primer for understanding research. Retrieved from http://web.b.ebscohost.com/ehost/ebookviewer/ ebook/bmxIYmtfXzExODAwNTBfXOFO0? sid=bf642a07-e3b6-463b-82d85467a0ffb19f@sessionmgr102\&vid=1\&format=EB\&rid=4

Bertram, C., \& Christiansen, I. (2014). Understanding research: An introduction to reading research. Retrieved from http://web.b.ebscohost.com/ehost/ ebookviewer/ebook/bmxlYmtfXzEyNDMwNDIfXOFO0?sid=bf642a07-e3b6-463b82d8-5467a0ffb19f@sessionmgr102\&vid=1\&format=EB\&rid=7

Blass, E. (2009). Talent management. New York, NY: Palgrave Macmillan, St Martin's Press LLC.

Bussin, M. (2014). Remuneration and talent management. Randburg: Knowres Publishing.

Chee, Y.P. (2017). The role of talent management in employee retention. Master's thesis, Durban University of Technology. Retrieved from http://eprints. utar.edu. my/2488/1/Thesis_Final_Copy_(1).pdf

CIPD. (August 2012). Talent management: an overview - Resource summary. Fact Sheet. Retrieved from http://www.cipd.co.uk/hr-resources/factsheets/talentmanagement-overview.aspx

Davies, J., \& Kourdi, J. (2010). The truth about talent. Wiley, UK: John Wiley and sons Ltd, Jossey Bass, A Wiley Imprint.

Davis, K. (2016). Stretch assignments: Give employees room to grow. Retrieved from https://www.gfoa.org/sites/default/files/GFR061624.pdf

Deloitte. (2015). Namibia human capital trends. Windhoek: Deloitte Development LLC.

Deloitte. (2020). COVID-19: Managing risks and ensuring business continuity. Downloaded 10 April 2020. Retrieved from https://www2.deloitte.com/cz/en/ pages/risk/solutions/covid-zajisteni-kontinuity-cinnosti.htm

Dhanpat, N., Modau, F.D., Lugisani, P., Mabojane, R., \& Phiri, M. (2018). Exploring employee retention to leave within a call centre. South Africa Publishing, 16, a905. https://doi.org/10.4102/sajhrm.v16i0.905

Erasmus, B.J., Grobler, A., \& Van Niekerk, M. (2015). Employee retention in higher education institution: An organisational development perspective. Progressio, 37(2), 33-63. https://doi.org/10.25159/0256-8853/600

Frost, S., \& Turner, D. (2016). Inclusive talent management: How business can thrive in an age of diversity. Kogan Page. Retrieved from https://library.books24x7.com/ assetviewer.aspx?bookid=115180\&chunkid=1\& rowid=2

Garg, D., \& Rani, K. (2014). Talent management: Empirical research results. International Journal of Management and Commerce Innovations, 2(1), 289-295.

Hatum, A., \& Preve, L.A. (2015). Managing talent risk. Havard Deusto Journal, 4(1), 34-45. https://doi.org/10.3926/hdbr.70

Kibui, A.W., Gachunga, H., \& Namusonge, G.S. (2014). Role of talent management on employee retention in Kenya. International Journal of Science and Research, 3(2), 414-422.

Koranteng, F.A. (2014). Assessing talent management as a tool for employee retention. Master's thesis, Kwame Nkrumah University. Retrieved from http://ir.knust.edu. $\mathrm{gh} /$ bitstream/123456789/7636/1/Frederick\%20Addy\%20Koranteng $\% 20$ $\% 28$ PG7604212\%292-1.pdfs

Lawler, E.E. (2017). Performance management. Oakland: Berrett-Koehler. Retrieved Sep 16, 2019 from https://library.books24x7.com/assetviewer.aspx?bookid=1203 $37 \&$ chunkid $=508609524 \&$ rowid $=175$

Letchmiah, L., \& Thomas, A. (2017). Retention of high potential employees in a development finance company. SAJHRM, 15, a924. https://doi.org/10.4102/ sajhrm.v15i0.924

Mahlahla, L.T. (2018). The impact of talent management on employee retention strategies. Master's thesis, Durban University of Technology. Retrieved from https://ir.dut.ac.za/bitstream/10321/3118/1/MAHLAHLALT_2018.pdf

Mamun, C.A., \& Hasan, N.H. (2017). Factors affecting employee turnover and sound retention strategies in business organisation: A conceptual view. Emerald Insight, 15(1), 63-71. https://doi.org/10.21511/ppm.15(1).2017.06

Mogwere, P.G. (2014). The relationship between talent management, employee engagement and service quality of support staff in a South African higher education institution. Master's thesis, North West University. Retrieved from education institution. Master's thesis, North West University. Retrieved from
https://pdfs.semanticscholar.org/4f4c/3df48c7d8adaea8ba0c416522fa367d1d1 https://pd 
Nambira, G., \& Enkali, E. (2019). Work engagement at a transforming tertiary institution: A reflection of NUST academic staff, Namibia. IJARBAS.COM, 1(2), 4-5. Retrieved from https://www.ijarbas.com/wp-content/uploads/2019/08/1.2-14Work-Engagement-at-A-Transforming-Tertiary-Institution-A-Reflection-of-NUSTAcademic-Staff-Namibia.pdf

Narayanan, A. (2016). Talent management and employee retention: Implications of job embeddedness - A research agenda. Papers Ssrn. Retrieved from https://papers.ssrn.com/sol3/papers.cfm?abstract id $=2829273$

Onyango, P.O., Nzulwa, J., \& Kwena, R. (2017). Influence of talent management on employee retention in public hospitals in Kenya: A case study of Siaya. The Strategic Journal of Business \& Change Management, 4(2), 631-642.

Ott, D.L., Tolentino, L., \& Michailova, S. (2018). Effective talent retention approaches. Retrieved from https://www.emerald.com/insight/content/ doi/10.1108/HRMID-07-2018-0152/full/html

Poisat, P., Mey, M., \& Sharp, G. (2018). Do talent management strategies influence the psychological contract within a diverse environment? South Africa Publishing, 16 a1044. https://doi.org/10.4102/sajhrm.v16i0.1044

Pregnolato, M., Bussin, M.H., \& Schechter, A.F. (2017). Total rewards that retain: A study of demograpwalhic preferences. South Africa Publishing, 15, a804. https:// doi.org/10.4102/sajhrm.v15i0.804

Riccio, S. (2010). Talent management in higher education: Development of emerging leaders within the administration at private colleges and universities. Doctoral dissertation, University of Nebraska. Retrieved from https:// digitalcommons.unl.edu/cgi/viewcontent.cgi?article $=1034 \&$ context=cehsed ddiss

Robertson, R. (2015). 5 Steps to integrating coaching into your talent management strategy. Retrieved from https://www.shrm.org/resourcesan $\mathrm{dtools/hr-topics/talent-acquisition/pages/coaching-talent-management-}$ strategy.aspx

Silzer, R., \& Dowell, B.E. (2010). Strategy - Driven talent management. Wiley, USA: John Wiley and sons, Jossey Bass, A Wiley Imprint.
Sparrow, P., \& Cooper, C. (2017). A research agenda for human resources management. Retrieved from http://web.a.ebscohost.com/ehost/detail/ detail?vid =2\&sid=06ea31cb-52c4-4d41-be7c16723c969e75\% 40 sessionmgr4 $006 \&$ bdata $=$ JnNpdGU9ZWhvc3QtbGI2ZQ\%3d\%3d\#AN $=1617392 \& d b=$ nlebk

Sparrow, P., Scullion, H., \& Tarique, I. (2014). Strategic talent management: Contemporary issues in an international context. Cambridge University Press. Retrieved from https://library.books24x7.com/assetviewer.aspx?bookid=69075\& chunkid $=607330436 \&$ rowid $=29$

Sparrow, P.R., \& Makram, H. (2015). What is the value of talent management? Building value-driven process within a talent management architecture. Human Resources Management Review, 25(2015), 249-263. https://doi.org/10.1016/j. hrmr.2015.04.002

Tetik, S. (2016). Talent management: A review of theoretical perspectives and a guideline for practitioners. Nile Journal of Business and Economics, 2(4), 40-56.

Theron, M., Barkhuizen, N., \& Du Plessis, Y. (2014). Managing the academic talent: Investigating factors in academic turnover and retention in South Africa. South Africa Publishing, 40(1), a1117. https://doi.org/10.4102/sajip.v40i1.1117

Turner, P., \& Kalman, D. (2014). Make your people before you make your products: Using talent management to achieve competitive advantage in global organisation. Wiley. Retrieved from https://library.books $24 \times 7 . c o m /$ assetviewer. aspx ?bookid $=72832 \&$ chunkid $=900006977 \&$ rowid $=207$

Van Hoof, E. (2020, 09 April). Lockdown is the world's biggest psychologica experiment - And we will pay the price. World Economic Forum. Retrieved from https://www.weforum.org/agenda/2020/04/this-is-the-psychologicalside-of-the-covid-19-pandemic-that-were-ignoring/

Van Zyl, E.S., Mathafena, R.B., \& Ras, J. (2017). The development of a talent management framework for the private sector. South Africa Publishing, 15, a820. https://doi.org/10.4102/sajhrm.v15i0.820

Wiley, R. (2013). What are qualitative research ethics? Bloomsbury Academy. Retrieved from https://books.google.com.na/books?id=HV9MAQAAQBAJ\&pg= Retrieved from https://books.google.com.na/books?id=HVGMAQAAQBAJ\&pg hUKEwjP6eT1trroAhXFSXUIHccoA6406AEITTAF\#v=onepage \&q=ethical\%20 considerations $\% 20$ in $\% 20$ qualitative $\% 20$ research $\& f=$ false 